\title{
COMPARATIVE ANALYSIS OF FOREIGN TRADE IN SELECTED EUROPEAN COUNTRIES
}

\author{
Jaroslav Kovarnik ${ }^{1, a,{ }^{*}}$ and Eva Hamplova ${ }^{2, b}$ \\ ${ }^{1}$ University of Hradec Králové, Faculty of Informatics and Management, Department of Economics, \\ Rokitanského 62, 50003 Hradec Králové, Czech Republic \\ ${ }^{2}$ University of Hradec Králové, Faculty of Informatics and Management, Department of Economics, \\ Rokitanského 62, 50003 Hradec Králové, Czech Republic \\ ajaroslav.kovarnik@uhk.cz, beva.hamplova@uhk.cz \\ *Corresponding author
}

Cite as: Kovarik, J., Hamplova, E. (2018). Comparative analysis of foreign trade in selected European countries, Ekonomicko-manazerske spektrum, 12(2), 106-117.

Available at: dx.doi.org/10.26552/ems.2018.2.106-117

\begin{abstract}
Foreign trade plays important role in the economy of every country. It not only solves the proportionality problem and builds the demonstrative effect, but most of all, it supports economic development. This article deals with selected aspects of foreign trade in countries from central Europe, namely in the Czech Republic, Slovakia, Poland, Hungary, Germany, and Austria. The Czech Republic, Slovakia, Poland, and Hungary are members of so called Viszegrad Four, where Germany and Austria are neighbours of some of these countries, but also very important business partners for them. Methods of comparative analysis and of point rating have been used in this article, where special attention has been placed on three different topics. First one is about comparative analysis of economic development in mentioned countries, especially about the GDP development and foreign trade development. Second one is about the verification of hypothesis about openness of the economy, where theory claims that strong and large countries are usually less open, compared to weak and small countries. According to this proclamation should be Germany, Austria, and Poland less open than the other analysed countries. Two different calculations have been used for verification of this hypothesis. Third topic is about the development of foreign trade in the countries with and without Euro. Germany, Austria, and Slovakia have been using Euro as domestic currency, where other analysed countries have their own currencies. The article compares the development in these countries with the aim to find similarities and differences.
\end{abstract}

Keywords: Central Europe, export, foreign trade, globalization, import

JEL Classification: F43, F49, O11

\section{Introduction}

Foreign trade is very important for every state all around the world because it is, among others, part of macroeconomic Gross Domestic Product (GDP) formula. In other words, it can either improve the GDP level (in case that export is higher than import) or worsen it (in the opposite case). This basic theory has been explained in many books and articles, for example in Andrews, Bernake \& Croushore (2011), or Samuelson \& Nordhaus (2010).

Nevertheless, foreign trade is important for every country because of other reasons as well. In almost all countries worldwide, foreign trade helps solving the proportionality problem, where only few countries have all necessary resources in quantities required for economic 
development. Foreign trade also has demonstrative effect and other benefits too, such as support of peaceful cooperation among partners, reducing of the risk of conflict, growth of education, and others.

From above mentioned text is clear that foreign trade is very important for every country. The importance of foreign trade has been evaluated in other articles by other authors. Some of them are analysing international trade from more theoretical point of view, for example Broda \& Weinstein (2006), Chen \& Juvenal (2018), Cernohlavkova et al. (2013), Do \& Levchenko (2007), Do, Levchenko \& Raddatz (2016), Ready, Roussanov \& Ward (2017), or Vannoorenberghe (2014). The other authors are using more global point of view, such as Baier, Bergrstrand \& Feng (2014), Cieslik, Bieganska \& Sroda-Murawska (2016), Cieslik, Bieganska \& Sroda-Murawska (2016), Colantone \& Sleuwaegen (2010), Gnangnon (2018), McCalman (2018), Reimer (2006), Samarina et al. (2015), or Yanase \& Tawada (2017). Other authors are analysing role of companies in foreign trade or the impact of foreign trade on companies, like Bergstrand \& Egger (2007), Ellis (2003), Fracasso \& Marzetti (2015), Helpman, Melitz \& Rubinstein (2008), Levchenko (2007), Niepmann \& Schmidt-Eisenlohr (2017), or Oh, Travis Selmier \& Lien (2011). Authors themselves already analysed the topic of foreign trade several times, for example in Kovarnik \& Hamplova (2016), or Kovarnik \& Hamplova (2017).

The Czech Republic is a member state of Visegrad Four, and all other member states (namely Poland, Slovakia, and Hungary) are very important business partners for the Czech Republic. Situation in Visegrad Four countries has been also analysed by other authors, for example by Clarke \& Slovik (2007), or Sacio-Szymanska et al. (2016). However, there are other important economies in the central Europe, namely Germany and Austria, where these two countries are not only strong and powerful economies, but also important business partners for whole V4. All analysed countries are member states of EU, where foreign trade in EU has been also analysed in several papers, e.g. in Curzi et al. (2018), Giordano \& Zollino (2016), Gladkov (2016), Mandel \& Tran (2017), or Paskrtova (2016).

The aim of this article is to analyse the selected aspects of foreign trade in above mentioned countries, namely in the Czech Republic, Poland, Hungary, Slovakia, Austria, and Germany. Firstly, this article analyses the development of GDP in selected countries, because of the importance of foreign trade for this indicator. Secondly, the article analyses the openness of selected countries with the aim to verify the hypothesis that strong and large countries are usually less open, compared to weak and small countries. According to this proclamation should be Germany, Austria, and Poland less open than the other analysed countries. Last analysed topic is about the development of foreign trade in the countries with and without Euro. Germany, Austria, and Slovakia have been using Euro as domestic currency, where other analysed countries have their own currencies.

\section{Methodology and Data}

Covered period of time is 2000-2017, where data were obtained in general available database Eurostat and calculated by authors (Eurostat a, 2018, Eurostat b, 2018).

Methods of comparison and comparative analysis have been used. Moreover, several different calculations can be used for the verification of above mentioned hypothesis about openness of economy. One of the most frequently used calculations measures the relation between export and GDP, where more open economies usually have high ratio. Another possible calculation uses import or turnover of foreign trade (summary of both export and import) on GDP, where authors have decided to compare the openness of the economy also by import on GDP ratio. 
Moreover, the comparison of these macroeconomic indicators from analysed countries has been done through point rating. Every economy can get the number of points given by the formula:

$$
y=\frac{x-x_{\min }}{x_{\max }-x_{\min }} \cdot 100
$$

where $y$ means the number of points, $x$ presents the value of each macroeconomic indicator for every year and every country, $x_{\min }$ is minimal value of this indicator from all countries and the whole analysed period, and finally $x_{\max }$ is the maximum one. Immediately from (1) it is clear that $y \in[0,100]$, the value for the worst result of $x$ is $y=0$, and the value for the best result of $x$ is $y=100$. The coefficient $y$ is computed by one of the possible data transformation methods called nonmetric scaling; more details can be found in. (James, 2016)

It is also important to add that the calculations are made per capita. It is quite obvious that the position of Germany is completely different from the other countries in absolute amounts, because it is not only powerful economy, but it has also the highest number of inhabitants (Germany has more than 82.5 billion in 2017, where Poland has almost 38 billion, the Czech Republic around 10.5 billion, Hungary almost 10 billion, Austria almost 9 billion, and Slovakia around 5.5 billion). Therefore it is almost impossible to compare absolute amounts and all calculations have been made per capita, where such recalculation allows to compare even such different economies.

\section{Results}

\subsection{GDP Development Analysis}

Based on number of inhabitants is quite obvious that the level of GDP in billions of euro is the highest in Germany, and second highest in Poland, where these two countries have significantly more number of inhabitants than the others. However, on the third position is Austria next is the Czech Republic, after that Hungary, and Slovakia is on the last position.

As was already explained, it is better to use the level of GDP per capita for comparison. According to this, the highest level is in Austria, Germany is on the second position, the Czech Republic is on the third place, Slovakia is the fourth, Hungary on the fifth place, and Poland is the last. With respect to this information is good to add one interesting fact. Even if the development in the number of inhabitants in each country has not been steady, this number grew in Austria, in Germany, in the Czech Republic and in Slovakia (comparison of the number of inhabitants in the years 2000 and 2017), while it dropped in Hungary and Poland.

Deep analysis of GDP development shows that in all analysed countries was significant decrease in this indicator in the year 2009 (both in absolute value and in per capita) as a result of global economic crisis. However, the after crisis development is different. All countries were growing since 2009, but only Austria, Germany, and Slovakia managed to exceed pre-crisis year 2008 already in 2010, where other countries achieved higher value later (2011 in case of the Czech Republic and Poland, and 2015 in Hungary). Moreover, the after-crisis development is different. Austria, Germany, and Slovakia have been growing since 2009 for the whole analysed period, where the Czech Republic was decreasing between 2012 and 2014, and it has been growing again since 2015. Hungary has been increasing since the 2009 with the only exception in 2012, and Poland has been also increasing for the whole after-crisis period with the only exception in 2016.

It is quite interesting that Slovakia as the only V4 member has similar development in terms of GDP per capita as advanced economies Germany and Austria. On the other hand, its level of 
GDP per capita is significantly weaker. However, its position is getting better, where Slovakia was on the last position in 2000, it is already better than Hungary and Poland, and it is getting closer to the Czech Republic. Following Table 1 describes the values of GDP per capita, where Table 2 describes the year-to-year growth rates in all analysed countries.

Table 1: GDP per Capita in Analysed Countries after Global Economic Crisis

\begin{tabular}{llllllllll}
\hline & 2000 & 2001 & 2002 & 2003 & 2004 & 2005 & 2006 & 2007 & 2008 \\
\hline Czech Republic & 6,503 & 7,368 & 8,534 & 8,658 & 9,419 & 10,749 & 12,123 & 13,487 & 15,596 \\
Germany & 25,759 & 26,500 & 26,799 & 26,898 & 27,512 & 27,889 & 29,031 & 30,532 & 31,158 \\
Hungary & 5,023 & 5,891 & 7,064 & 7,440 & 8,287 & 9,007 & 9,109 & 10,150 & 10,763 \\
Austria & 26,694 & 27,494 & 28,118 & 28,624 & 29,763 & 30,980 & 32,447 & 34,285 & 35,359 \\
Poland & 4,871 & 5,553 & 5,495 & 5,031 & 5,397 & 6,449 & 7,197 & 8,233 & 9,607 \\
Slovakia & 4,139 & 4,438 & 4,890 & 5,594 & 6,460 & 7,324 & 8,474 & 10,467 & 12,277 \\
\hline & 2009 & 2010 & 2011 & 2012 & 2013 & 2014 & 2015 & 2016 & 2017 \\
\hline Czech Republic & 14,261 & 14,980 & 15,643 & 15,367 & 15,000 & 14,902 & 15,987 & 16,711 & 18,116 \\
Germany & 30,003 & 31,540 & 33,695 & 34,338 & 35,098 & 36,383 & 37,549 & 38,451 & 39,715 \\
Hungary & 9,397 & 9,868 & 10,146 & 10,018 & 10,282 & 10,688 & 11,235 & 11,569 & 12,605 \\
Austria & 34,558 & 35,430 & 37,030 & 37,898 & 38,324 & 39,148 & 40,128 & 40,607 & 42,140 \\
Poland & 8,315 & 9,515 & 9,990 & 10,230 & 10,371 & 10,811 & 11,316 & 11,219 & 12,261 \\
Slovakia & 11,895 & 12,537 & 13,097 & 13,453 & 13,708 & 14,049 & 14,553 & 14,956 & 15,636 \\
\hline
\end{tabular}

Source: Own calculations based on Eurostat A (2017) and Eurostat B (2017)

Table 2: Year-to-Year GDP per Capita Growth Rate in Analysed Countries

\begin{tabular}{llllllllll}
\hline & 2001 & 2002 & 2003 & 2004 & 2005 & 2006 & 2007 & 2008 & 2009 \\
\hline Czech Republic & $13.30 \%$ & $15.83 \%$ & $1.46 \%$ & $8.79 \%$ & $14.12 \%$ & $12.78 \%$ & $11.25 \%$ & $15.63 \%$ & $-8.56 \%$ \\
Germany & $2.87 \%$ & $1.13 \%$ & $0.37 \%$ & $2.28 \%$ & $1.37 \%$ & $4.09 \%$ & $5.17 \%$ & $2.05 \%$ & $-3.71 \%$ \\
Hungary & $17.30 \%$ & $19.90 \%$ & $5.33 \%$ & $11.38 \%$ & $8.69 \%$ & $1.14 \%$ & $11.42 \%$ & $6.04 \%$ & $-12.69 \%$ \\
Austria & $3.00 \%$ & $2.27 \%$ & $1.80 \%$ & $3.98 \%$ & $4.09 \%$ & $4.74 \%$ & $5.66 \%$ & $3.13 \%$ & $-2.26 \%$ \\
Poland & $13.99 \%$ & $-1.03 \%$ & $-8.45 \%$ & $7.28 \%$ & $19.50 \%$ & $11.58 \%$ & $14.40 \%$ & $16.70 \%$ & $-13.45 \%$ \\
Slovakia & $7.22 \%$ & $10.19 \%$ & $14.38 \%$ & $15.49 \%$ & $13.37 \%$ & $15.71 \%$ & $23.52 \%$ & $17.29 \%$ & $-3.11 \%$ \\
\hline Czech Republic & $5.04 \%$ & $4.43 \%$ & $-1.76 \%$ & $-2.39 \%$ & $-0.65 \%$ & $7.28 \%$ & $4.53 \%$ & $8.40 \%$ & \\
Germany & $5.13 \%$ & $6.83 \%$ & $1.91 \%$ & $2.22 \%$ & $3.66 \%$ & $3.20 \%$ & $2.40 \%$ & $3.29 \%$ & \\
Hungary & $5.02 \%$ & $2.81 \%$ & $-1.26 \%$ & $2.64 \%$ & $3.95 \%$ & $5.11 \%$ & $2.98 \%$ & $8.95 \%$ & \\
Austria & $2.52 \%$ & $4.52 \%$ & $2.35 \%$ & $1.12 \%$ & $2.15 \%$ & $2.50 \%$ & $1.19 \%$ & $3.78 \%$ \\
Poland & $14.44 \%$ & $4.99 \%$ & $2.40 \%$ & $1.38 \%$ & $4.24 \%$ & $4.67 \%$ & $-0.86 \%$ & $9.30 \%$ \\
Slovakia & $5.39 \%$ & $4.47 \%$ & $2.71 \%$ & $1.89 \%$ & $2.49 \%$ & $3.59 \%$ & $2.77 \%$ & $4.55 \%$ & \\
\hline
\end{tabular}

Source: Own calculations based on Eurostat A (2017) and Eurostat B (2017)

Relatively high values of growth rates in Poland and Hungary are probably consequence of relatively low values of GDP per capita, where even relatively small increase leads into high growth rate. On the other hand, it is quite obvious that Slovakia has been growing since 2010, but this growth rate is relatively low, where the Czech Republic was decreasing till 2014, but the growth rate since 2015 is relatively high. This development only supports partial conclusion mentioned above about the similar development in Slovakia, Germany, and Austria. All of these countries have been growing since economic crisis, where other V4 members had some problematic years. On the other hand, the growth rate in Germany and Austria is relatively low (because of the strong economic position in these countries), as well as in Slovakia, where all other V4 countries have had after crisis some relatively strong years with high year-to-year growth rate. 


\subsection{The Analysis of the Openness of the Economy}

As was already described, the openness of the economy can be evaluated by several methods. The authors of this article decided to use export on GDP ratio (following Figure 1) and import on GDP ratio (following Figure 2).

Figure 1: Export on GDP Ratio

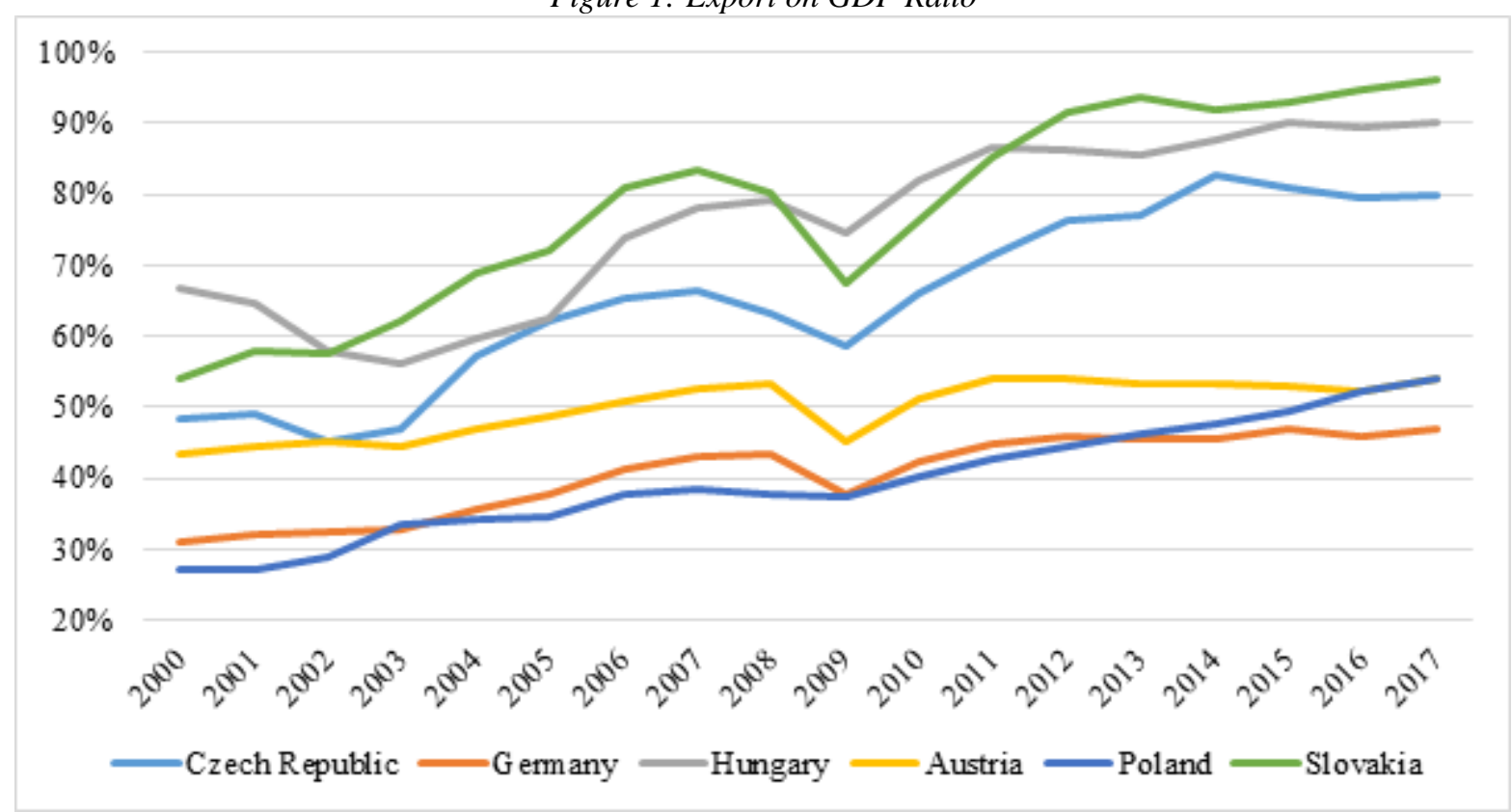

Source: Own calculations based on Eurostat A (2017) and Eurostat B (2017)

As was described in introduction, theory claims that strong, large and powerful economies are usually less open compared to weak, small countries. Based on this fact can be assumed that Germany, Austria, and Poland should be less open than the Czech Republic, Hungary, and Slovakia. Germany is both huge and powerful economy; Austria is relatively small, but economically strong and powerful economy, where Poland is economically relatively weak, but large country with a lot of inhabitants. The Czech Republic, Hungary, and Slovakia are relatively small and weak countries.

Both figures prove this theoretical assumption. Even if the differences among countries in 2000 were not so significant (neither in export on GDP, nor in import on GDP), in 2017 is quite obvious that there exist two different groups of countries. The Czech Republic has export share almost $80 \%$ (it was more than $80 \%$ in 2014 and 2015) and import share more than $70 \%$, in Hungary is export share more than $90 \%$ and import share more than $80 \%$, and both share are more than $90 \%$ in Slovakia. On the other hand, export share is only a little bit than $47 \%$ in Germany, almost 54\% in Austria, and a little bit than 54\% in Poland, where import share is little bit over 50\% in Austria, almost 50\% in Poland, and even less than $40 \%$ in Germany. 
Figure 2: Import on GDP Ratio

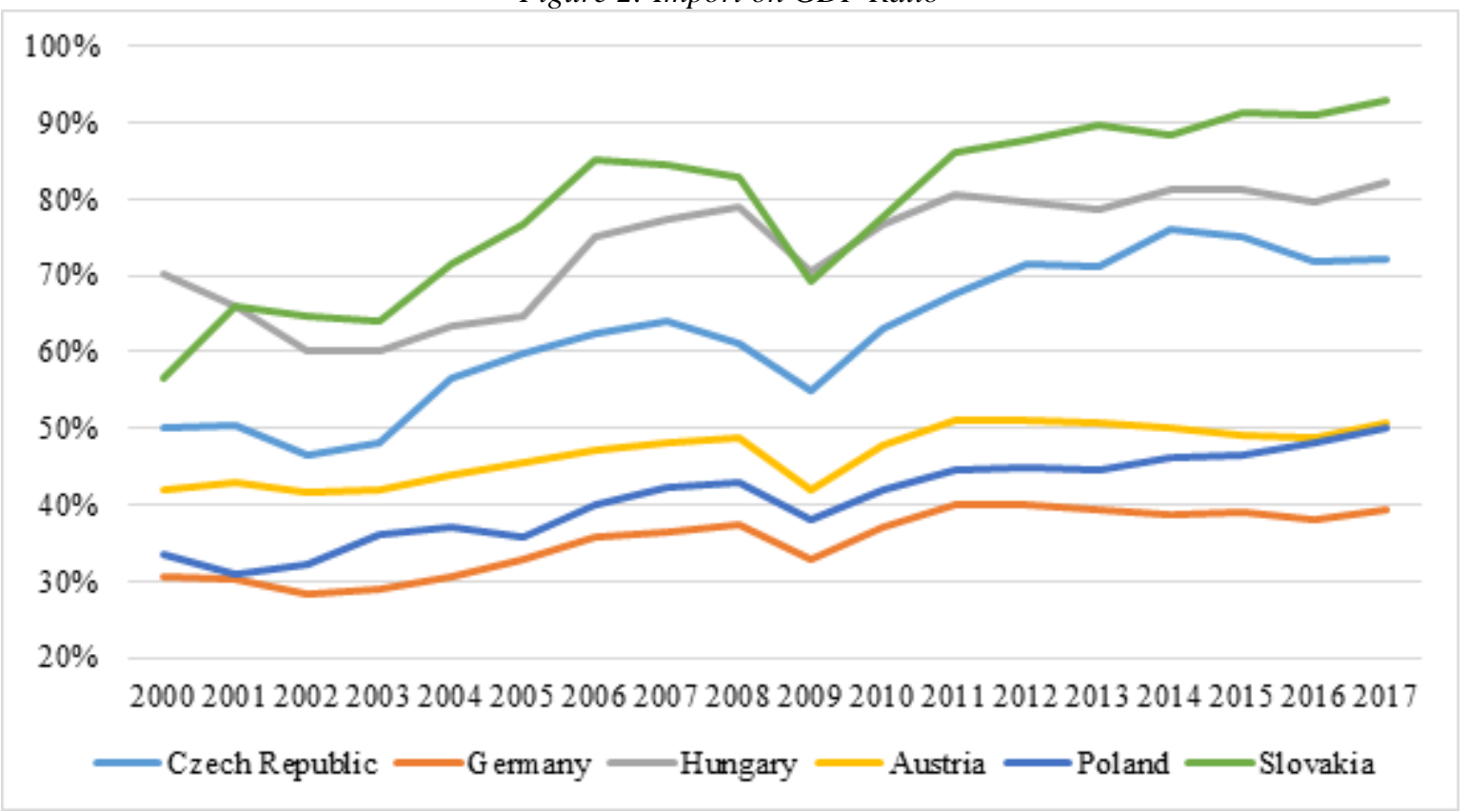

Source: own calculations based on Eurostat A (2017) and Eurostat B (2017)

There exist only few differences in the development of export on GDP and of import on GDP. In case of import, Germany has been the weakest for the whole analysed period, where in case of export it exceeded Poland for few years. Hungary had the highest export on GDP ratio in crisis year, where in case of import is this ratio almost the same as in case of Slovakia. It is also possible to see higher fluctuation in import on GDP development. Possible explanation can be in theoretical assumption that export has only autonomous part, where import has both autonomous and induced part.

In spite of the irregular development, a following partial conclusion can be made. The theory about the connection between the size of the country and its economic level, and the openness of such country has been proven. Small and weak analysed countries are more dependent on foreign trade, where large or economically strong economies are less dependent. Germany is both large and economically powerful economy, but Austria is relatively small, and Poland is relatively economically weak, but even so are these two countries relatively closed. It can be explained in that way that Poland, even if it is economically weak, is able to obtain a lot of necessary products in homeland, because it has a lot of inhabitants and a lot of natural resources. On the other hand, Austria is relatively small country, it probably needs a lot of product from foreign countries, but it is economically powerful, and therefore it is not so dependent on foreign trade, because GDP is generated from other (domestic) subjects.

\subsection{The Analysis of the Foreign Trade Development}

Last analysed topic in this article is about the development of foreign trade in countries with Euro and without Euro. As was already mentioned, Germany, Austria and Slovakia have been using Euro as domestic currency, where the Czech Republic has Czech crown, Poland has zloty, and Hungary has forint. Moreover, Germany and Austria were the original members of Eurozone, where Slovakia entered this organization in 2009. This chapter analysed the development of foreign trade with the aim to compare the development in the countries with the Euro and without Euro. 
The balance of foreign trade with goods and services in billions of euro again proofs the strong economic position of Germany and Austria compared to other evaluated countries. In 2000, only Germany and Austria had positive balance, where all V4 members had negative trade balance. In 2017, the balance of Germany is almost 250,000 billion euro, where second Poland has positive trade balance almost 20,000 billion euro. It is obvious that the Germany is far more powerful than other countries. Interesting fact is that Austria is on fourth position, where not only Poland, but also the Czech Republic has higher trade balance. That means that the growth rate of foreign trade balance in V4 countries has been higher than in case of Austria. However, because of the strong position of Germany, trade balance is again calculated per capita in following Figure 3. The net balance shows a little bit different results after this recalculation. The highest net balance per capita is still in in Germany, but on the second position is already the Czech Republic, Austria is the third, and Poland is on the last position.

Figure 3: Net Balance in Terms of Goods and Services per Capita

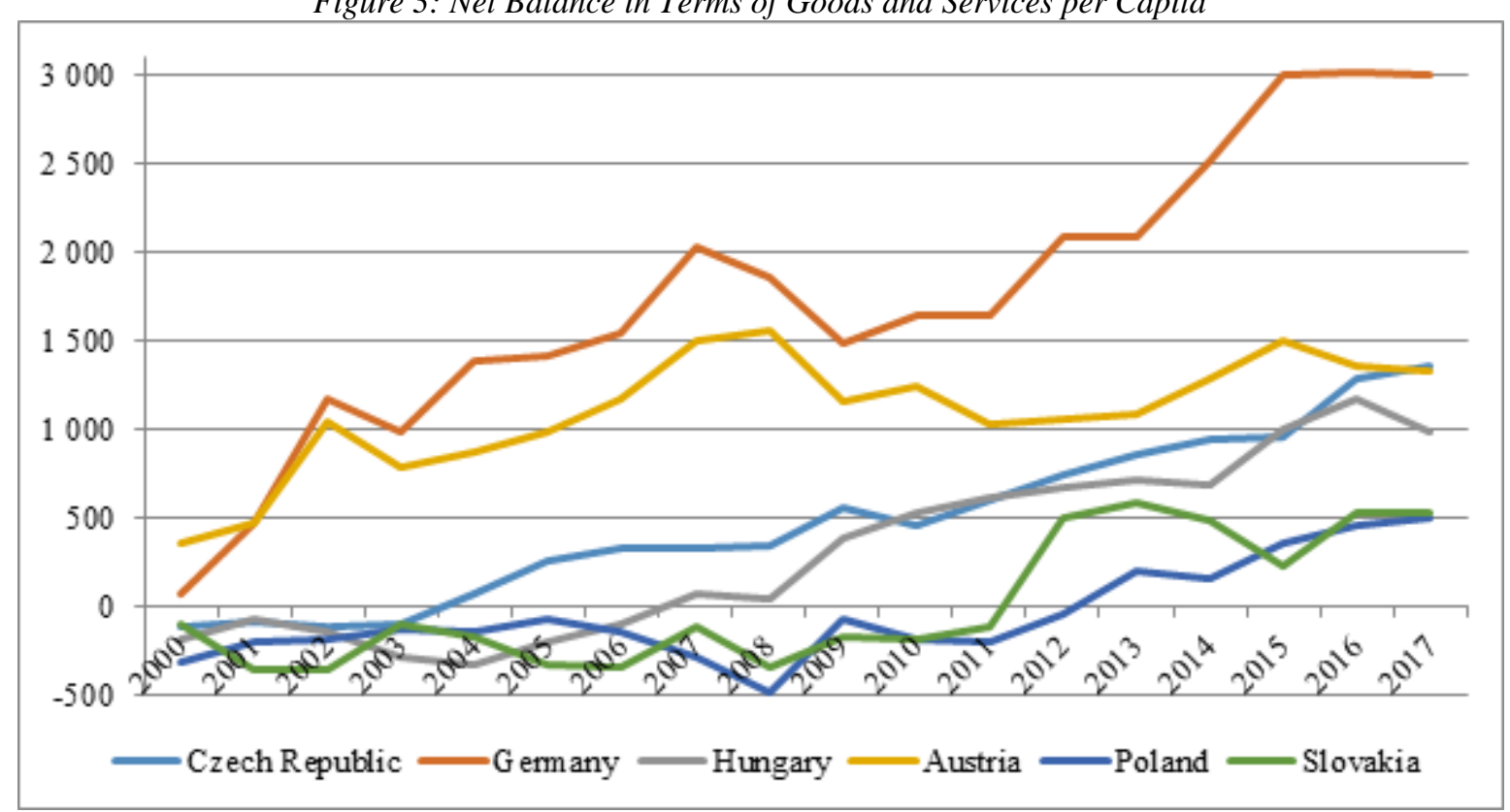

Source: Own calculations based on Eurostat A (2017) and Eurostat B (2017)

It is quite obvious that the fact of same or different currency has no direct impact on the development of net balance. Germany has been growing significantly, but this growth rate is probably the consequence of strong economic position of this Country. Foreign trade is not so important in this county, Germany can be considered as relatively closed economy, but it still can generate a lot from foreign trade. On the other hand, it can generate a lot from the trade with goods; relatively surprising fact is that in trade with services only is Germany in negative balance.

Austria had the highest trade balance per capita in 2000, but the growth rate has not been as rapid as in Germany, and it is on the third position in 2017. On the other hand, the Czech Republic was on the fourth position in 2000 , the growth rate was relatively high, and it is on the second position in 2017, even if this country has own currency. The trade in Slovakia has not been steady, but it is not possible to see any significant increase after the entrance to the Eurozone. Significant growth occurred in 2012, but it has been followed by another unstable development.

Relatively interesting fact is that in 2009, in the year of economic crisis, the net balance per capita decreased in Germany and Austria, while it increased in all V4 member states. 
To sum it up, partial conclusion can be made that there is no obvious increase of trade in countries with common currency. The development of net balance of foreign trade is probably influenced by other factors. This topic has been already analysed more briefly by authors in other articles, for example Kovarnik \& Hamplova (2016) or Kovarnik \& Hamplova (2017).

\subsection{The Analysis of Development of the Foreign Trade with Services}

From above mentioned Figure 3 has been described the development of net balance with goods and services. However, relatively surprising results can be seen in the analysis of foreign trade with services only. Results of net balance per capita are described in the following Figure 4.

Figure 4: Net Balance in Terms of Services per Capita

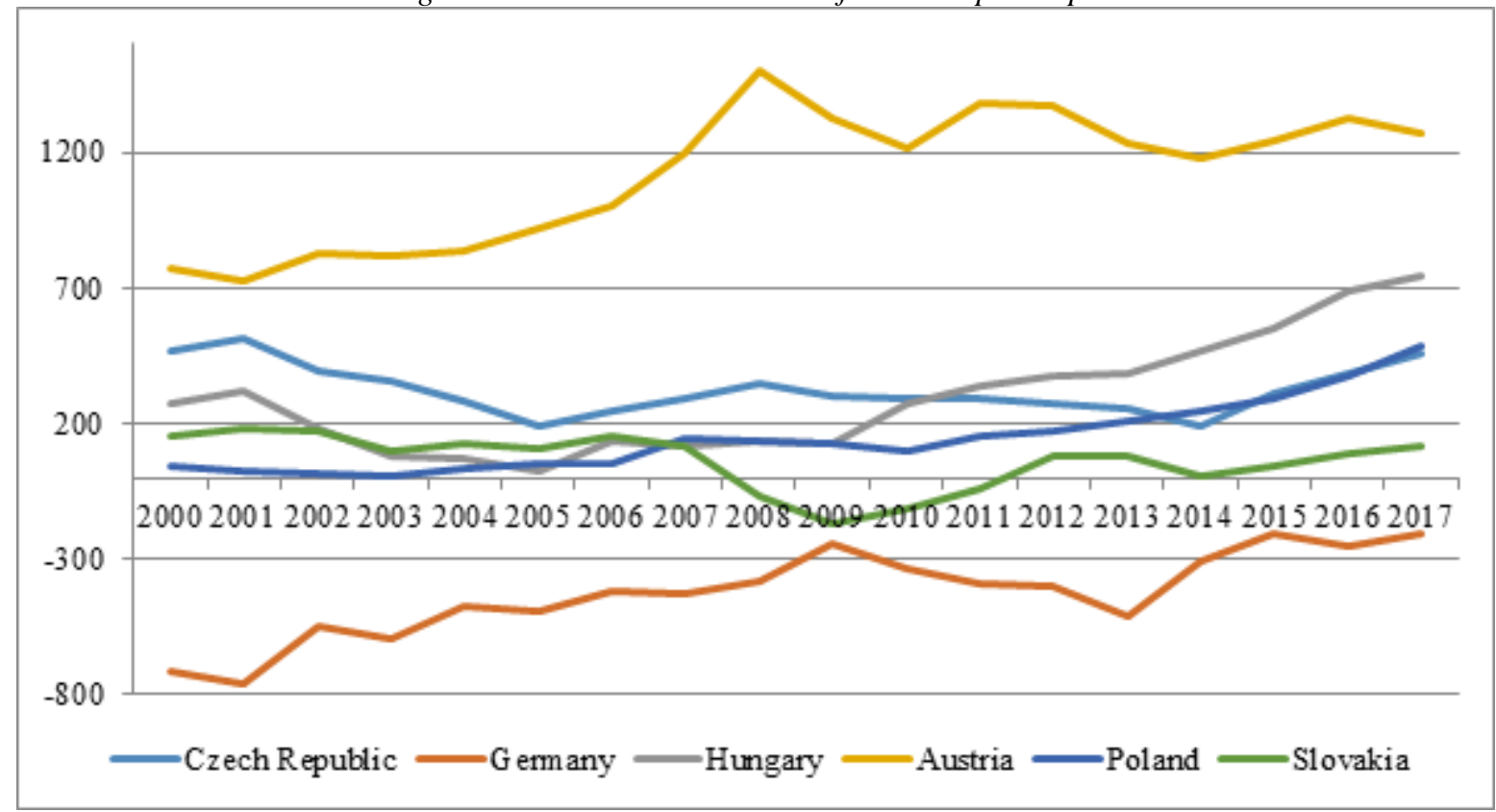

Source: Own calculations based on Eurostat A (2017) and Eurostat B (2017)

It is quite obvious that Germany is strongly oriented on trade with goods. Total net balance is in huge surplus in this country, where the net balance in services only is in deficit for the whole analysed period. Moreover, result of this country is the worst from all analysed countries. Another country with short period of deficit was Slovakia, but results in this country were better than in Germany.

The highest surplus per capita is in Austria. This country is not only on the second place in total net balance, but also on the first place in terms of services only. This result only supports the position of Austria as the strongest country from all analysed countries.

Relatively strong position in services has Hungary; this country is on second position in net balance per capita. The Czech Republic and Poland have similar results, where Slovakia is the weakest from all V4 countries.

Nevertheless, overall development is relatively stable in terms of services. Germany and Austria have been growing in analysed period (comparison of 2000 and 2017), but the increase is not as big as in terms of total net balance. Visegrad Four countries have had more or less similar results in 2017 as in 2000.

It can be explained in that way that in all analysed countries plays trade with goods more significant role. This domination is obvious especially in Germany, where trade with services is in deficit, but overall net balance has been growing significantly. In other analysed countries 
has been net balance with services stable or growing slowly, but even in these countries has been overall development growing quickly.

\subsection{The Analysis of Development of the Foreign Trade by Nonmetric Scaling}

The authors have used method of nonmetric scaling in this part of the article for the analysis of foreign trade development. Nonmetric scaling is the method, where available macroeconomic data are recalculated into standardized data. For purpose of this article have been analysed different macroeconomic indicators connected with foreign trade, namely [A] GDP per capita in $€$; [B] Balance of goods per capita in $€$; [C] Balance of services per capita in $€$; [D] Balance of goods and services per capita in $€$. Data have been analysed in the period $2000-2017$, where each economy has received number of points based on its position (see Methodology).

Based on data it is possible to see (Figure 5) that the best economy in the year 2017 was Germany, the country with the highest number of inhabitants. However, the number of inhabitants is not important any more in case of other analysed countries. The second strongest country in this analysis is Austria, where this country is ten times smaller than Germany. On the other hand Poland, country four times bigger than the Czech Republic, Hungary, or Austria, has the smallest rating. The overall development of point rating in analysed period $2000-2017$ described in the Figure 6 shows the main points for foreign trade evaluation in analysed countries. The most developed between 2000 and 2011 was Austria, where this changed in 2012. The most developed country after the global economic crisis has become Germany. It has got a huge lead not only before Austria, but of course before other V4 countries.

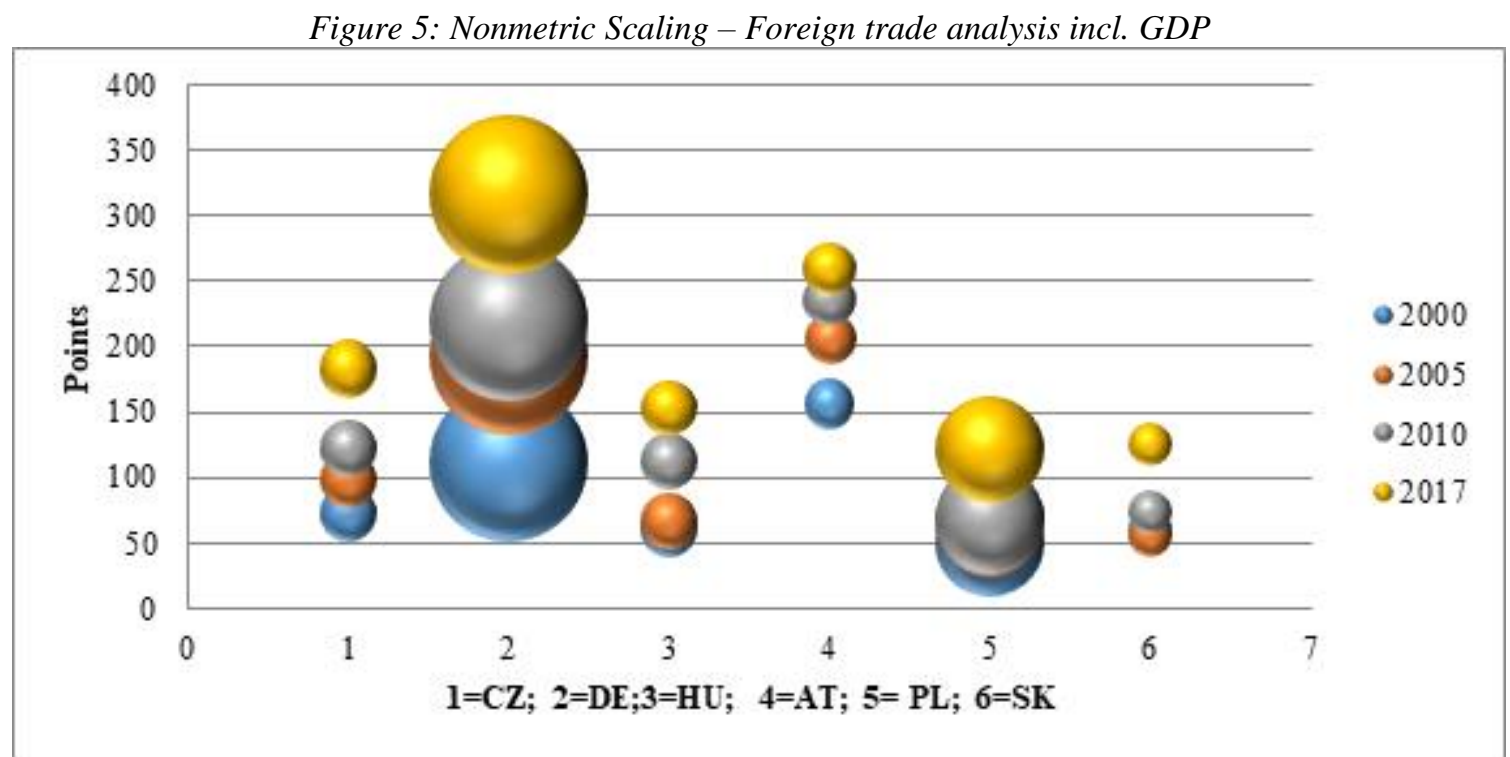

Source: Own calculations based on Eurostat A (2017) and Eurostat B (2017)

The dynamics of foreign trade development and GDP development occurred most significantly in the shift of position of Germany between 2000 and 2005. There was increase for $74 \%$, where its point rating changed from 111 points to 194 points. On the other hand, Slovakia decreased from 61 to 56 points in this period. Between 2006 and 2010 was economic crisis in all analysed countries, where the most significant impact of crisis was in Germany and Austria in 2009, and in Poland and Slovakia in 2008. The position of Hungary was not affected by crisis, moreover, its position changed from 65.5 to 112 points between 2006 and 2010, which was increase for almost 71\%. Between 2011 and 2017 has been developing especially Germany, 
where its position has achieved 317 points in 2017. Relatively huge increase has been in Poland and Slovakia as well. Points in Poland has increased for $76 \%$ (from 69 to 121 points) and for $70 \%$ in Slovakia (from 73.5 to 125 points).

Figure 6: Development of points in 2000 - 2017 [years, points]; [A] GDP per capita in $\epsilon ;$ [B] Balance of goods

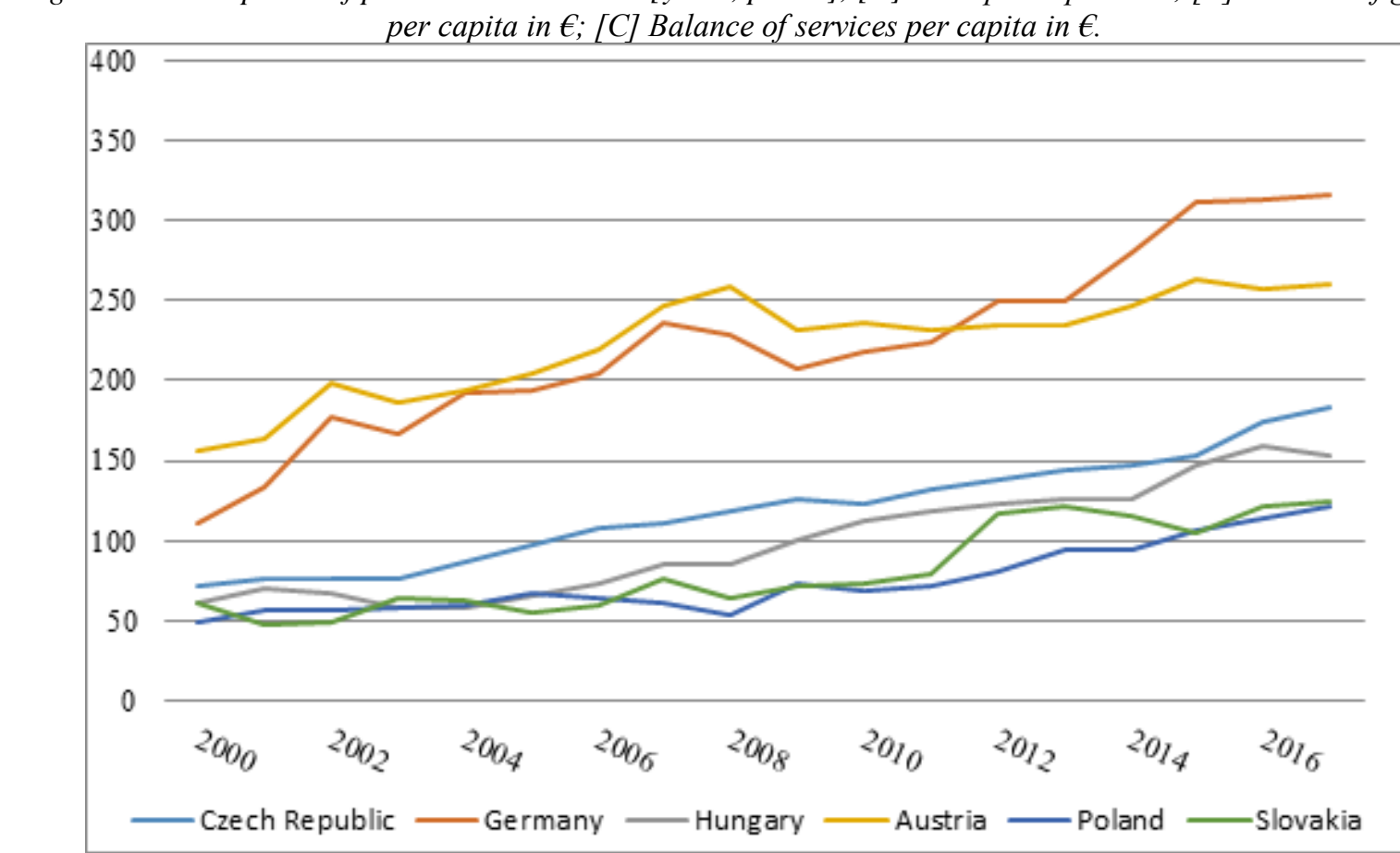

Source: Own calculations based on Eurostat A (2017) and Eurostat B (2017)

\section{Discussion}

It is possible to make a partial conclusion about dynamic development of advanced economies regardless their sizes (both Germany and Austria), where V4 countries (again regardless their sizes) have been lagging and developing slowly (especially between 2000 and 2007). Economic crisis had bigger influence on developed countries, after crisis has been developing especially Germany, where Austria has been lagging in complex development (more precisely, its level is almost the same as before crisis). Countries of V4 have been developing relatively rapidly after crisis. Complex analysis of foreign trade of selected countries is finished by point rating. This rating evaluates economies by four different macroeconomic indicators, where these indicators are important for evaluation of economic position of every country, and therefore this rating helps to evaluate mutual convergence of these indicators. It is not surprise that V4 countries have high degree of similarity, but on the other hand, it is possible to see some tendencies of better development in the Czech Republic and Hungary, even if these countries have significantly lower amount of inhabitants compared to Poland. The position of Austria is extraordinary, where this country has similar number of inhabitants as the Czech Republic or Hungary, but its point rating has been extreme during the whole analysed period, where its point rating is comparable with Germany.

\section{Conclusion}

This article deals with several foreign trade topics in selected countries from Central Europe, namely in Austria, Germany, the Czech Republic, Slovakia, Poland, and Hungary. Firstly, the 
development of GDP per capita has been evaluated, because foreign trade is important part of GDP formula of every open economy in current globalized world.

This analysis shows expected result that the strongest economy is Austria followed by Germany. The position of these countries is far better than the position of V4 countries, where the strongest one is the Czech Republic followed by Slovakia.

Second analysed topic has been openness of the economy, which can be measured by several different methods. One of the most frequently used is the export on GDP ratio. Based on this calculation can be the Czech Republic, Slovakia, and Hungary considered as relatively open economies, where Austria, Germany, and Poland are relatively closed ones. This result is not surprising in case of Germany, which is both large and economically powerful country, but it can be relatively surprising in case of Poland and Austria. Poland is large country with a lot of inhabitants, but it is economically weak. Austria, on the hand, is small country with less than 10 billion of inhabitants, but it is economically very powerful.

Last analysed topic has been the development of foreign trade in the countries with Euro compared with the countries without this currency. Germany and Austria have been using Euro for the whole analysed period, Slovakia has been using Euro since 2009, and other analysed countries have their own currencies. However, the simple fact of same currency has no obvious impact on the development of foreign trade. Other influences affecting foreign trade have probably stronger impact on this development.

To sum it up, foreign trade is very complex topic. It can be analysed from a lot of different perspectives, it is possible to use a lot of special or general statistical tools, but limited space of this article allows analysing only few selected topics with basic descriptive analysis. Nevertheless, even without statistical calculation are some conclusion relatively surprising. The authors would like to continue in this analysis in following papers.

\section{References}

Andrews, A.B., Bernake, B. \& Croushore, D.D. (2011). Macroeconomics, 6th ed. Boston: Addison-Wesley.

Baier, S.L., Bergrstrand, J. H. \& Feng, M. (2014). Economic Integration Agreements and the Margins of International Trade. Journal of International Economics, 93, 339-350.

Bergstrand, J.H. \& Egger, P. (2007). A Knowledge-and-Physical-Capital Model of International Trade Flows, Foreign Direct Investment, and Multinational Enterprises. Journal of International Economics, 73, 278-308.

Broda, C. \& Weinstein, D.E. (2006). Globalization and the Gains from Variety. Quarterly Journal of Economics, $121,541-585$.

Chen, N. \& Juvenal, L. (2018). Quality and the Great Trade Collapse. Journal of Development Economics, 135 , 59-76.

Cieslik, E., Bieganska, J. \& Sroda-Murawska, S. (2016). The Intensification of Foreign Trade in Post-Socialist Countries and Their Role in Global Value Chain. Acta Oeconomica, 66, 465-487.

Clarke, D. \& Slovik, P. (2007). Modeling of Exports Flows in the Visegrad Sub-region. Ekonomicky Casopis, 55, 747-761.

Colantone, I. \& Sleuwaegen, L. (2010). International Trade, Exit and Entry: A Cross-Country and Industry Analysis. Journal of International Business Studies, 41, 1240-1257.

Curzi, D., Luarasi, M., Raimondi, V. \& Olper, A. (2018). The (Lack of) International Harmonization of EU Standards: Import and Export Effects in Developed versus Developing Countries. Applied Economics Letters, 25, 1552-1556.

Cernohlavkova, E., Machkova, H., Sterbova, L. \& Zadrazilova, D. (2013). Foreign and Domestic Trade - The History and Development of Science Branch. Politicka Ekonomie, 61, 555-567.

Do, Q.T. \& Levchenko, A.A. (2007). Comparative Advantage, Demand for External Finance, and Financial Development. Journal of Financial Economics, 86, 796-834.

Do, Q.T., Levchenko, A.A. \& Raddatz, C. (2016). Comparative Advantage, International Trade, and Fertility. Journal of Development Economics, 119, 148-166.

Ellis, P.D. (2003). Social Structure and Intermediation: Market-Making Strategies in International Exchange. Journal of Management Studies, 40, 1683-1708. 
Eurostat A, (August 2018). International Trade of EU, the Euro Area and the Member States. [Online]. Available: http://ec.europa.eu/eurostat/web/international-trade/data/database.

Eurostat B, (August 2018). GDP and Main Components. [Online]. Available: http://ec.europa.eu/eurostat/web/national-accounts/data/database.

Fracasso, A. \& Marzetti, G.V. (2015). International Trade and R\&D Spill Overs. Journal of International Economics, 96, 138-149.

Giordano, C. \& Zollino, F. (2016). Shedding Light on Price- and Non-price-competitiveness Determinants of Foreign Trade in the Four Largest Euro-area Countries. Review of International Economics, 24, 604-634.

Gladkov, I.S. (2016). European Union in Modern International Trade. Contemporary Europe-Sovremennaya Evropa, 1, 85-94.

Gnangnon, S.K. (2018). Impact of Trade Imbalances on Domestic Trade Policy: Does Multilateral Trade Policy Matter? Review of Development Economics, 22, 1266-1289.

Helpman, E., Melitz, M. \& Rubinstein, Y. (2008). Estimating Trade Flows: Trading Partners and Trading Volumes. Quarterly Journal of Economics, 123, 441-487.

James, S. (2016). An Introduction to Data Analysis Using Aggregation Functions in R. Cham: Springer.

Kovarnik, J. \& Hamplova, E. (2016). The Analysis of Foreign Trade Development in the Countries of Visegrad Four. Proceedings of $19^{\text {th }}$ International Colloquium on Regional Sciences. Brno, Czech Republic, 240-246.

Kovarnik, J. \& Hamplova, E. (2017). Selected Topics of Foreign Trade in the Czech Republic and in Slovakia. Proceedings of $17^{\text {th }}$ International Scientific Conference Globalization and Its Socio-Economic Consequences. Rajecke Teplice, Slovakia, 1112-1120.

Levchenko, A.A. (2007). Institutional Quality and International Trade. Review of Economic Studies, 74, 791-819.

Mandel, M. \& Tran, V.Q. (2017). An Empirical Verification of Export Function Focused on the Impact of EUR/CZK Exchange Rate. Politicka ekonomie, 65(6), 649-668.

McCalman, P. (2018). International Trade, Income Distribution and Welfare. Journal of International Economics, $110,1-15$.

Niepmann, F. \& Schmidt-Eisenlohr, T. (2017). International Trade, Risk and the Role of Banks. Journal of International Economics, 107, 111-126.

Oh, C.H., Travis Selmier, W. \& Lien, D. (2011). International Trade, Foreign Direct Investment, and Transaction Costs in Languages. Journal of Socio-Economics, 40, 732-735.

Paskrtova, L. (2016). Dependence of Slovak Economy Growth on Foreign Trade. Proceedings of $16^{\text {th }}$ International Scientific Conference Globalization and Its Socio-Economic Consequences. Rajecke Teplice, Slovakia, 16421648.

Ready, R., Roussanov, N. \& Ward, C. (2017). Commodity Trade and the Carry Trade: A Tale of Two Countries. Journal of Finance, 72, 2629-2684.

Reimer, J.J. (2006). Global Production Sharing and Trade in the Services of Factors. Journal of International Economics, 68, 384-408.

Sacio-Szymanska, A., Kononiuk, A., Tommei, S., Valenta, O., Hideg, E., Gaspar, J., Markovic, P., Gubova, K. \& Boorova, B. (2016). The Future of Business in Visegrad Four. European Journal of Futures Research, 4, 25 37.

Samarina, E.A., Petrova, A.D., Blazhenkova, N.M. \& Aznabaeva, G.H. (2015). Sanctions by the WTO Member Countries as a Catalyst for the Development of a Competitive Import Substitution by Domestic Enterprises. Journal of Advanced Research in Law and Economics, 6, 775-784.

Samuelson, P.A. \& Nordhaus W.D. (2010). Economics, 19th ed. Boston: McGraw-Hill/Irwin.

Vannoorenberghe, G. (2014). International Trade, Risk Taking and Welfare. Journal of International Economics, 92, 363-374.

Yanase, A. \& Tawada, M. (2017). Public Infrastructure for Production and International Trade in Small Open Economy: A Dynamic Analysis. Journal of Economics, 121, 51-73. 